Arq. Bras. Med. Vet. Zootec., v.66, n.1, p.15-21, 2014

\title{
Mitral flow propagation velocity in non-sedated healthy cats
}

\author{
[Velocidade de propagação do fluxo mitral em gatos saudáveis e não sedados] \\ A.C. Silva, R.A.L. Muzzi, G. Oberlender, L.A.L. Muzzi, M.R. Coelho, R.B. Nogueira \\ Universidade Federal de Lavras -UFLA - Lavras, MG
}

\begin{abstract}
Mitral flow propagation velocity $(\mathrm{Vp})$ is an index used to evaluate the left ventricular diastolic function. Its influence on human and small animal cardiopathies has been studied; however there are few reports evaluating this variable in domestic felines. In addition, there is a lack of studies in non-sedated healthy cats. Therefore, the purpose of this study was to establish values for $\mathrm{Vp}$ and its correlation with other echocardiographic indexes in non-sedated healthy cats in order to provide new perspectives related to diastolic function in this species. Twenty-six clinically healthy cats were submitted to echocardiography to assess the animals' cardiac conditions. Variables such as age, heart rate (HR), body surface area (BSA), initial (E mitral) and late (A mitral) ventricular filling waves, isovolumic relaxation time (IVRT) and E/IVRT relation were correlated to Vp. No proven relation between any of these variables and Vp was observed in this present study, except for HR and BSA. In the variability analysis, higher values were verified for inter-observer analysis. This study concludes that $\mathrm{Vp}$ proved to be an useful index for estimating left ventricular relaxation in non-sedated healthy domestic cats and provides reference ranges for this variable.
\end{abstract}

Keywords: feline, cardiopathies, echocardiography, diastolic function

\section{RESUMO}

A velocidade de propagação do fluxo mitral (Vp) é um índice utilizado para avaliação da função diastólica do ventrículo esquerdo. Sua importância nas cardiopatias em humanos e pequenos animais vem sendo estudada; porém, há poucos trabalhos avaliando essa variável em gatos domésticos. Nessa espécie, estudos utilizando animais saudáveis e não sedados não foram encontrados na literatura. Dessa forma, objetivou-se estabelecer os valores da Vp e sua correlação com outros índices ecocardiográficos em gatos domésticos saudáveis e não sedados, de forma a fornecer novas perspectivas relacionadas à função diastólica nessa espécie. Foram utilizados 26 gatos domésticos clinicamente saudáveis, submetidos à ecocardiografia para se avaliar a condição cardíaca dos animais. As variáveis idade, frequência cardíaca $(F C)$, área de superfície corporal (SAC), idade, onda de enchimento ventricular inicial (E mitral) e tardio (A mitral), tempo de relaxamento isovolumétrico (TRIV) e a relação E/TRIV foram correlacionadas com a Vp. No presente estudo não foi observada correlação da Vp com nenhuma das variáveis estudas, exceto com a FC e o SAC. Quanto à análise de variabilidade, foi observado um maior valor para a análise inter-observador. O estudo permite concluir que a Vp demonstrou ser um índice útil para se estimar o relaxamento ventricular esquerdo em gatos domésticos saudáveis e não sedados, além de fornecer valores de referência para essa variável.

Palavras-chave: felino, cardiopatias, ecocardiografia, função diastólica

Recebido em 22 de outubro de 2012

Aceito em 17 de julho de 2013

E-mail: adrianagudi@gmail.com 


\section{INTRODUCTION}

Echocardiography is the non-invasive tool of choice for cardiac function assessment in cats, once it enables an observation of the heart in real-time as well as flows and valve morphology achievement, besides being an evaluation of the cardiac chambers size (Bonagura, 2000).

Many echocardiographic techniques such as Doppler and two dimensional speckle tracking have been used in veterinary medicine in order to better understand the physiopathology of cardiac abnormalities in cats, as well as obtain their diagnoses (Chetboul et al., 2006; Koffas et al., 2006; Adin and Diley-Poston, 2007; Wess et al., 2010).

Left ventricular (LV) diastolic dysfunction is an important cause of clinical symptoms and is considered one of the first functional abnormalities detected in a large number of cardiopathies (Schober et al., 2003; 2010). In this context, hypertrophic cardiomyopathy (HCM) is considered one of the most common cardiac abnormalities in domestic cats and it often leads to the onset of cardiac heart failure (CHF) symptoms or even sudden death of asymptomatic animals (Ferasin, 2009; Silva et al., 2013). The physiopathological mechanism is primarily related to diastolic dysfunction which is responsible for HCM clinical symptoms, since an abnormal relaxation pattern can cause abnormal rise of ventricular filling pressure, hence an atrial enlargement (Côtè et al., 2011).

Mitral flow propagation velocity $(\mathrm{Vp})$ is an echocardiographic variable used to determine left ventricular diastolic function. This index has been studied in medicine with the aim to characterize its influence in either healthy or sick individuals in different hemodynamic conditions (Rivas-Gotz et al., 2003; Kidawa et al., 2005; Khalaf, 2012). In veterinary medicine, Vp has been mainly evaluated in dogs with degenerative myxomatous mitral valve disease (DMVD) to obtain its true importance and influence over other variables (Schober et al., 2010). Other studies evaluated $\mathrm{Vp}$ in dogs with induced $\mathrm{CHF}$ (Schober et al., 2008), and with dilated cardiomyopathy (O’Sullivan et al., 2007). According to the study of Cavalcanti et al. (2007), Vp is a relatively independent index in boxer breed dogs. Furthermore, they verified in their study that $\mathrm{Vp}$ is inversely proportional to the animals' age.

There are few studies available on $\mathrm{Vp}$ in nonsedated healthy felines as well as in cardiopathic ones. A study conducted with sedated cats showed that $\mathrm{Vp}$ was not influenced by preload values and nor by heart rate (Schober et al., 2003). The study conducted by Ward et al. (2012) showed that Vp suffers small variation in animals which were anesthetized with acepromazine + butorphanol or acepromazine + butorphanol + ketamine.

Despite the different echocardiographic techniques used in veterinary medicine that became recently available, there is still much to study on cardiac function in cats as well as on cardiovascular variations that may develop in this species. Thus, to better understand the clinical significance of variations in feline echocardiography, it is essential to obtain reference values from non-sedated healthy subjects, since such knowledge can aid in early diagnosis of cardiac diseases. Therefore, the aim of this study was to evaluate the values obtained for $\mathrm{Vp}$ as well as its correlation with variables such as age, heart rate (HR), body surface area (BSA), initial (E mitral) and late (A mitral) ventricular filling waves, isovolumic relaxation time (IVRT) and E/IVRT ratio since there is little information available about the influence of $\mathrm{Vp}$ on these variables in non-sedated healthy cats.

\section{MATERIALS AND METHODS}

In order to conduct this study, twenty-six domestic cats from the small animal service of the institution were examined. A prior consent from the owners was obtained and the project was approved by the Ethics on Animals Use Committee under the number 052/11. All the animals were clinically examined. Systolic blood pressure (Doppler indirect method), thoracic radiography (right lateral and ventrodorsal recumbency), electrocardiography (ECG) and echocardiography were performed for assessing whether the animals were healthy.

An Esaote ${ }^{\circledR}$ (Mylab 40) ultrasound machine with a $4-10 \mathrm{MHz}$ sectorial scanning transducer and a simultaneous ECG monitor were used in order to perform the echocardiography. The animals were gently positioned on the left and right 
lateral recumbence without sedation while the exam was being processed. The images and echocardiographic measurements were obtained in the right parasternal short axis view, right longitudinal parasternal and left apical 4chambers view. The assessment of systolic and diastolic left ventricular dimensions were made through the M-mode echocardiography, and the ratio between the left atrium (LA) and aorta dimensions were evaluated through two dimensional mode. Moreover, valve flows were measured by pulsed Doppler as well as early (E) and late (A) mitral valve ventricular filling waves and isovolumic relaxation time (IVRT) of the LV. The ratio among E/A, E/Vp and E/IVRT were calculated subsequently. All echocardiographic indices and variables achieved were accomplished following the criteria recommended by Boon (2011).

In order to assess $\mathrm{Vp}$, the M-mode was accomplished with the cursor positioned over the mitral valve, while the color Doppler was activated. Thus, with an enlarged image it was possible to visualize mitral flow being spread into LV. According to recommendations by Schober et al. (2003), Vp was measured from the opening of the mitral valve leaflet through 1.5 $\mathrm{cm}$ distance inside the $\mathrm{LV}$ with the aid of a line drawn in the color change zone (blue-red) of wave E (Fig. 1).

All results from continuous variables were clearly investigated and the test for normality (Kolmogorov-Smirnov) was performed. A descriptive analysis was done as well as the frequency analysis for categorical variables (gender and breed) and also for continuous variables with the purpose of obtaining median (age) and mean (weight, BSA and echocardiographic variables). The correlation between $\mathrm{Vp}$ and other echocardiographic parameters was enabled by the use of Sperman's correlation test. The Vp variability was observed (intra and interobserver variability) and assessed through the coefficient of variation $(\mathrm{CV}-\%)$ from duplicate measurements (Schober et al., 2010; Ward et al., 2012). In order to evaluate intraobserver variability, six animals were randomly selected and $\mathrm{Vp}$ was measured on the first and fifteenth day. For the assessment of interobserver variability, $\mathrm{Vp}$ was measured in these six animals by two examiners that were unaware of previous results. For measuring variability coefficient, the difference between the $\mathrm{CV}$ achieved on both analysis dates was calculated. For all analysis performed a $\mathrm{P}<0.05$ was considered statistically significant.

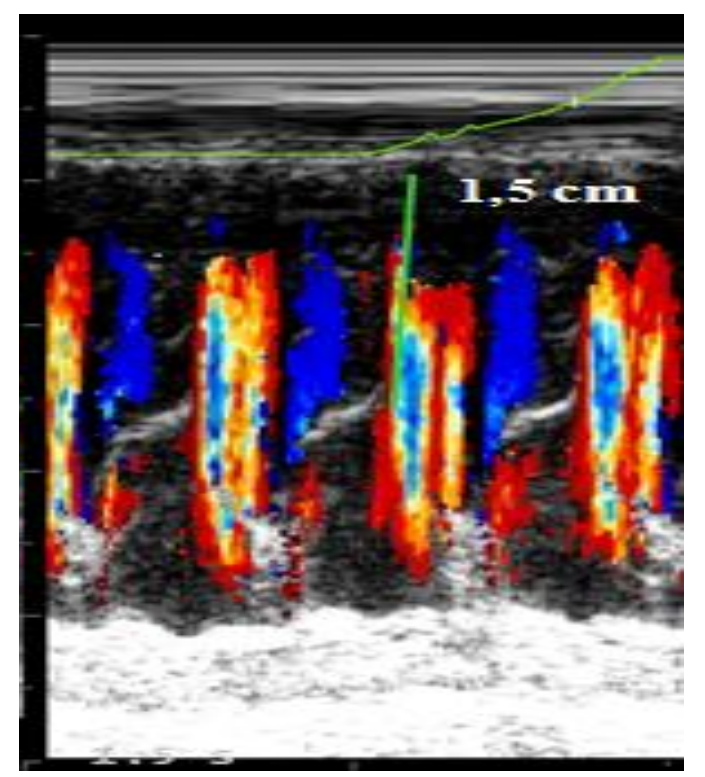

Figure 1. Mitral flow propagation velocity $(\mathrm{Vp})$ determined by the slope ramp (green line) positioned in the transitional color zone (redblue) from the opening of mitral valve leaflet through $1.5 \mathrm{~cm}$ distance inside $\mathrm{LV}$ in a nonsedated healthy cat

All statistical analyses were performed using SPSS for Windows version 17.0 (SPSS, 2008).

\section{RESULTS}

The animals presented mean values of systolic blood pressure within the normal range $(129.50 \pm 15.03 \mathrm{mmHg})$. No relevant variations were verified in the thoracic radiography and ECG did not show any myocardial electrical disturbance or arrhythmia.

The weight variations and BSA presented normal distribution data $(\mathrm{P}>0.05)$, since the average was $3.99 \pm 0.99 \mathrm{~kg}(2.5-6.8)$ and $0.25 \pm 0.04 \quad(0.18-$ $0.36)$, respectively. Regarding the animals' age, the distribution was not normal $(\mathrm{P}<0.05)$ and the median obtained was 24 months (7-84). Furthermore, regarding the gender variable, it was verified that $61.5 \%$ of the animals were males and $38.5 \%$ were females. Among these animals' sorts of breeding, there was one 
Siamese $(3.8 \%)$, six Persians $(23.1 \%)$ and 19 mixed breed animals $(73.1 \%)$.

In Table 1 the values (mean \pm standard deviation) are displayed for echocardiographic variables in this study, and all values are within the normal range (Schober et al., 2003; Boon, 2011). The mean value calculated for $\mathrm{Vp}$ in this present study was $0.71 \mathrm{~m} / \mathrm{s}$ and it was also observed a HR mean value with 162.63 beats per minute.

Table 2 shows the existing correlation between $\mathrm{Vp}$ and other variables in this study. A significant correlation of $\mathrm{Vp}$ could only be verified between $H R$ and BSA.

Table 1. Values for echocardiographic and heart rate in non-sedated healthy cats $(\mathrm{n}=26)$

\begin{tabular}{cccc}
\hline $\begin{array}{c}\text { Variable } \\
\text { analyzed }\end{array}$ & Mean \pm standard deviation & Minimum & Maximum \\
\hline Vp $(\mathrm{m} / \mathrm{s})$ & $0.71 \pm 0.11$ & 0.39 & 1.05 \\
A mitral (m/s) & $0.62 \pm 0.13$ & 0.40 & 0.93 \\
E mitral (m/s) & $0.89 \pm 0.14$ & 0.50 & 1.27 \\
E:A Ratio & $1.47 \pm 0.21$ & 1.04 & 2.15 \\
E:Vp Ratio & $1.28 \pm 0.31$ & 0.80 & 2.49 \\
IVRT (ms) & $41.50 \pm 9.31$ & 19 & 67 \\
E:TRIV Ratio & $0.0225 \pm 0.0067$ & 0.01 & 0.04 \\
Heart Rate (bpm) & $162.63 \pm 43.38$ & 55 & 239 \\
\hline
\end{tabular}

Vp: mitral flow propagation velocity; A mitral: late mitral valve ventricular filling wave; E mitral: early mitral valve ventricular filling wave; IVRT: isovolumic relaxation time.

Table 2. Sperman's coefficient for correlation between mitral valve flow propagation velocity (Vp) and echocardiographic parameters in non-sedated healthy cats $(n=26)$

\begin{tabular}{ccccccccc}
$\begin{array}{c}\text { Compared } \\
\text { Variables }\end{array}$ & $\begin{array}{c}\text { Age } \\
(\mathrm{months})\end{array}$ & BSA & $\begin{array}{c}\text { A mitral } \\
(\mathrm{m} / \mathrm{s})\end{array}$ & $\begin{array}{c}\text { E mitral } \\
(\mathrm{m} / \mathrm{s})\end{array}$ & $\begin{array}{c}\text { E:A } \\
\text { Ratio }\end{array}$ & $\begin{array}{c}\text { IVRT } \\
(\mathrm{ms})\end{array}$ & $\begin{array}{c}\text { E:IVRT } \\
\text { Ratio }\end{array}$ & $\begin{array}{c}\text { Heart } \\
\text { Rate }\end{array}$ \\
\hline $\begin{array}{c}\mathrm{Vp} \\
(\mathrm{m} / \mathrm{s})\end{array}$ & $\mathrm{r}=-0.268$ & $\mathrm{r}=-0.490^{*}$ & $\mathrm{r}=-0.014$ & $\mathrm{r}=0.010$ & $\mathrm{r}=0.021$ & $\mathrm{r}=0.159$ & $\mathrm{r}=-0.134$ & $\mathrm{r}=0.276^{*}$ \\
& $\mathrm{P}=0.185$ & $\mathrm{P}=0.013$ & $\mathrm{P}=0.882$ & $\mathrm{P}=0.912$ & $\mathrm{P}=0.819$ & $\mathrm{P}=0.076$ & $\mathrm{P}=0.136$ & $\mathrm{P}=0.05$
\end{tabular}

Vp: mitral flow propagation velocity; BSA: Body surface area; A mitral: late mitral valve ventricular filling wave; E mitral: early mitral valve ventricular filling wave; IVRT: isovolumic relaxation time.

*Significant correlation at level 0,05 .

Regarding intra and interobserver variabilities, $\mathrm{Vp}$ achieved higher values $(\mathrm{P}<0.05)$ for interobserver analysis (9.90\%) when compared with intraobserver variability $(7.57 \%)$.

\section{DISCUSSION}

The greater number of males, as well as the fact that most of the animals were young adults, may be explained by the random selection of animals examined in this study. Moreover, regional characteristics explain the fact of having a greater representation of mixed breed animals compared to other breeds.

The variable Vp showed slightly higher values when compared to those obtained by Schober et al. (2003), and lower values than the those obtained by Ward et al. (2012). In this last reference it was proved that $\mathrm{Vp}$ does not change in a clinically significant way after sedation. However, the number of animals tested in both studies was small $(n=7)$, which may have influenced the mean values observed and explains the differences obtained compared with the present study $(n=26)$.

The IVRT showed relevant value within the standard established by Boon (2011), which was similar to value obtained by Ward et al. (2012). However, this variable presented numerically lower than those achieved by Schober et al. (2003). The study performed by Ward et al. (2012) verified that a small variation of this variable exists when comparing non-sedated and sedated animals. Thus, the variation observed in relation to the study developed by Schober et al. (2003) may be attributed to the sedation procedure adopted in both studies. Furthermore, in dogs with DMVD, the cutoff-value for IVRT 
is $46 \mathrm{~m} / \mathrm{s}$, and lower values indicate worsening symptoms of their conditions and onset of $\mathrm{CHF}$ (Schober et al., 2010).

Concerning mitral flow, E and A waves showed higher mean values than those described in literature (Bright et al., 1999; Schober et al., 2003; Ward et al., 2012), and this fact can be explained by HR influence on mitral flow, once a higher HR can increase the values of waves $\mathrm{E}$ and A. However in the study of Santilli and Bussadori (1998) in non-sedated cats, lower values than those in our study were observed. On the other hand, the study mentioned was conducted over 10 years ago, so differences on ultrasound machine and its accuracy could be an explanation. In addition, E/A relation with values verified in this present study are higher than those reported by Ward et al. (2012) and lower than the values obtained by Schober et al. (2003), and identical to the value obtained by Soares et al. (2005); such variation can be a consequence of the sedation process, heart rate, and from the difference in the number of animals tested.

Vp did not correlate with A mitral, E mitral, E/A and IVRT ratio variables, and these findings are similar to what is described in literature, whether for studies in cats or in dogs (Schober et al., 2003; Cavalcanti et al., 2007; Schober et al., 2010). However, in the present study, Vp correlated significantly with BSA and HR, although the correlation coefficient is low ( $\mathrm{r}=$ 0.276). This fact differs from that observed in the study developed by Schober et al. (2003), in which Vp was not affected by HR. This can be justified by the influence of sedation on variables evaluated in the study. According to Cavalcanti et al. (2007), in which Vp was evaluated in Boxer breed dogs, there were no significant correlation of this variable with other echocardiographic indices, it only was verified an inverse relation with age. Thus, Vp was considered a relatively independent index. However, a correlation between $\mathrm{Vp}$ and the animals' age in the present study was not verified, there was only a relation between $\mathrm{Vp}$ and BSA, in which the correlation was negative. These differences may have occurred due to the difference between the species (cats and dogs) and the fact that the cats were not sedated in this present work.
Regarding intra and interobserver variabilities, a higher percentage of interobserver analysis was shown. However, all values were considered low, since they are below 15\%, just like the value achieved in other studies of this same variable (Schober et al., 2010; Ward et al., 2012). Additionally, interobserver variability was lower than that observed by Ward et al. (2012). Thus, Vp can be considered as an index with good reproducibility.

Some limitations found in this study should be clarified. Such limitations include problems in obtaining quality images of non-sedated cats, since the high heart rate of these animals makes the appropriate achievement of mitral flow and images for measuring $\mathrm{Vp}$ difficult. In addition, the study was conducted on 26 non-sedated cats with mixed breed animals being over represented and there were only few Persians and Siameses. Thus, developing a study involving a larger number of animals is essential in order to determine the influence of breed and gender on $\mathrm{Vp}$.

Another limitation that should be considered is the manual method of measuring $\mathrm{Vp}$ flow ramp, especially when this ramp looks nearly vertical, may raise the values of this variable (Schober $e t$ al., 2003). However, aiming to minimize these factors and increase the analysis reliability, a 1.5 $\mathrm{m} / \mathrm{s}$ sweep speed and five measurements of Vp per animal were adopted and performed as recommended by Schober et al. (2003). Furthermore, the present study was conducted in pet animals, so no invasive analysis for obtaining hemodynamic data was performed, in order to collaborate with the clinical conditions of the animals.

\section{CONCLUSIONS}

The present study provided information about $\mathrm{Vp}$ and its relevance for determining diastolic function in non-sedated healthy felines. Vp proved to be a useful index to estimate left ventricular relaxation in non-sedated healthy domestic cats, which contributed to the achievement of values that can be used as reference indexes in healthcare routine. $\mathrm{Vp}$ demonstrated to be a relatively independent index, and it can be used to obtain diastolic function in domestic cats. However, developing studies in cats with heart diseases to obtain Vp values and comparing them with ones obtained 
in healthy animals are essential to evaluate the role of this variable in the diagnosis of cardiac abnormalities in cats.

\section{ACKNOWLEDGEMENTS}

The authors would like to thank the Fundação de Amparo a Pesquisa do Estado de Minas Gerais (FAPEMIG), Coordenação de Aperfeiçoamento de Pessoal de Nível Superior (CAPES) and Conselho Nacional de Desenvolvimento Científico e Tecnológico (CNPq) for the financial support.

\section{REFERENCES}

ADIN, D.B.; DILEY-POSTON, L. Papillary muscle measurements in cats with normal echocardiograms and cats with concentric left ventricular hypertrophy. J. Vet. Intern. Med., v.21, p.737-741, 2007.

BONAGURA, J.D. Feline echocardiography. $J$. Feline Med. Surg., v.2, p.147-151, 2000.

BOON, J.A. Appendix four: feline. In: BOON, J.A. (Ed). Veterinary echocardiography. 2.ed. Iowa, USA: Wiley-Blackwell, 2011. p.569-580.

BRIGHT, J.M.; HERRTAGE, M.E.; SCHNEIDER, J.F. Pulsed Doppler assessment of left ventricular diastolic function in normal and cardiomyopathic cats. J. Am. Anim. Hosp. Assoc., v.35, p.285-291, 1999.

CAVALCANTI, G.A.O.; MUZZI, R.A.L.; ARAÚJO, R.B.; CHEREM, M. Avaliação ecodopplercardiográfica da função diastólica em cães da raça Boxer. Arq. Bras. Med. Vet. Zootec., v.59, p.1169-1176, 2007.

CHETBOUL, V.; SAMPEDRANO, C.C.; GOUNI, V. et al. Two-dimensional color tissue Doppler imaging detects myocardial dysfunction before occurrence of hypertrophy in a young Maine coon cat. Vet. Radiol. Ultras., v.47, p.295300, 2006.

CÔTÈ, E.; MAcDONALD, K.A.; MEURS, K.M.; SLEEPER, M.M. Hypertrophic cardiomyopathy. In: COTÈ, E.; MAcDONALD, K.A.; MEURS, K.M.; SLEEPER, M.M. (Eds). Feline cardiology. 1.ed. Iowa, USA: WileyBlackwell. Section D, ch. 11, 2011. p.135-246.
FERASIN, L. Feline myocardial disease: classification, pathophysiology and clinical presentation. J. Feline Med. Surg., v.11, p.3-13, 2009.

KIDAWA, M.; COIGNARD, L.; DROBINSKI, G. et al. Comparative value of tissue Doppler imaging and M-mode color Doppler mitral flow propagation velocity for the evaluation of left ventricular filling pressure. Chest, v.128, p.25442550, 2005.

KHALAF, M.M. Comparison between tissue Doppler imaging and color M-mode Doppler indices in LV systolic dysfunction patients with different filling pressures. J. Am. Sci., v.8, p.180184, 2012.

KOFFAS, H.; DUKES-McEWAN, J.; CORCORAN, B.M. et al. Pulsed tissue Doppler imaging in normal cats and cats with hypertrophic cardiomyopathy. J. Vet. Intern. Med., v.20, p.6577, 2006.

RIVAS-GOTZ, C.; MANOLIOS, M.; THOHAN, V.; NAGUEH, S.F. Impact of left ventricular ejection fraction on estimation of left ventricular filling pressures using tissue Doppler and flow propagation velocity. Am. J. Cardiol., v.91, p.780-784, 2003.

SANTILLI, R.A.; BUSSADORI, C. Doppler echocardiographic study of left ventricular diastole in non-anaesthetized healthy cats. Vet. J., v.156, p.203-215, 1998.

SCHOBER, K.E.; FUENTES, V.L.; BONAGURA, J.D. Comparison between invasive hemodynamic measurements and noninvasive assessment of left ventricular diastolic function by use of Doppler echocardiography in healthy anesthetized cats. Am. J. Vet. Res., v.64, p.93103, 2003.

SCHOBER, K.E.; STERN, J.A.; DACUNHA, D.N.Q.T. et al. Estimation of left ventricular filling pressure by Doppler echocardiography in dogs with pacing-induced heart failure. J. Vet. Intern. Med., v.22, p.578-585, 2008.

SCHOBER, K.E.; HART, T.M.; STERN, J.A. et al. Detection of congestive heart failure in dogs by Doppler echocardiography. J. Vet. Intern. Med., v.24, p.1358-1368, 2010. 
SILVA, A.C.; MUZZI, R.A.L.; OBERLENDER, G. et al. Feline hypertrophic cardiomyopathy: an echocardiography approach. Arch. Med. Vet., v.45, p.1-6, 2013.

SOARES, E.C.; LARSSON, M.H.M.A.; DANIEL, A.G.T. et al. Índices ecodopplercardiográficos de função diastólica de gatos saudáveis não sedados. Ciên. Rural., v.35, p.1357-1362, 2005.

SPSS Statistics 17.0, Rel. 17.0.1. SPSS Inc, Chicago, IL, 2008

O’SULLIVAN, M.L.; O'GRADY, M.R.; MINORS, S.L. Assessment of diastolic function by Doppler echocardiography in normal Doberman Pinschers and Doberman Pinschers with dilated cardiomyopathy. J. Vet. Intern. Med., v.21, p.81-91, 2007.
WARD, J.L.; SCHOBER, K.; FUENTES, V.L; BONAGURA, J. Effects of sedation on echocardiographic variables of left atrial and left ventricular function in healthy cats. J. Feline Med. Surg., v.14, p.678-685, 2012.

WESS, G.; SARKAR, R.; HARTMANN, K. Assessment of left ventricular systolic function by strain imaging echocardiography in various stages of feline hypertrophic cardiomyopathy. $J$. Vet. Intern. Med., v.24, p.1375-1382, 2010. 